\title{
Interleukin disappears from the literature
}

\section{Boston}

Two papers from Dr Ellis Reinherz's laboratory at Dana-Farber Cancer Institute that announced the discovery and properties of a T-cell activating substance termed interleukin-4A(IL-4A) have been retracted by the authors. The reason given for the retraction is that the data are incorrect and are not reproducible. The authors, in other words, no longer claim to have proof of the existence of IL-4A originally hailed as the chemical messenger that amplifies the body's immune response by turning on resting $T$ cell's, through its interaction with the T11 protein at the surface of the T cell.

The papers being retracted were published in Science (231, 1118; 1986 by Claudio Milanese, Neil E. Richardson and Ellis L. Reinherz) and the Journal of Experimental Medicine (163, 1583; 1986 by Claudio Milanese, Robert E. Siliciano, Reinhold E. Schmidt, Jerome Ritz, Neil F. Richardson and Ellis L. Reinherz). Letters of retraction are being sent to both journals.

An ad hoc committee of scientists from both within and outside Dana-Farber is investigating why the papers need to be retracted. Both Reinherz and David Kiszkiss, director of research at the institute, refused to comment on the reasons the data became suspect, how the data were proved incorrect, or why a retraction of the articles was necessary even before an investigation was completed. It is possible that litigation may result, according to Reinherz; but a final decision will be up to Dana-Farber and its parent Harvard Medical School or perhaps the National Institutes of Heath (NIH), Kiszkiss says.

Kiszkiss refused to comment on the process of data review at Dana-Farber or in the Reinherz laboratory. Dr Sheldon Wolff of the New England Medical Center, says any person in a laboratory understands there will be efforts to reproduce all published data. There is no way the principal scientist can be expected to stand at the elbow of everyone working in a laboratory, says Wolff. The work of Reinherz is unanimously described as "impeccable" by others in the field.

The withdrawal of the IL-4A papers means there is now only one well-studied candidate for a T11 ligand, a molecule termed LFA3. The data supporting the existence and activity of this molecule are so convincing, says Dr Peter Beverley at the Imperial Cancer Research Fund in London, that "a number of people were sceptical of the dramatic announcement" of IL-4A. According to Dr Stephen Shaw of NIH, a principal investigator of LFA3, there is much interest in finding the one or more molecules that interact with $\mathrm{T} 11$, also called CD2. T11 is a marker on T cells thought to be involved in adhesion of lymphocytes and triggering of T-cell activation. IL-4A was described as soluble, of low molecular weight, and responsible for triggering resting T cells. LFA3 is a much larger cell-bound molecule responsible for lymphocyte adhesion.

Shaw says he originally accepted the IL4A data because they came from the Reinherz laboratory and because there is room on the T11 molecule for two different recognition sites. He also thought IL$4 \mathrm{~A}$ could be a soluble fragment of LFA3. Even though there is no longer proof of the molecule termed IL-4A, he says, other ligands for the "popular and trendy" T11 molecule may exist, including (he speculates) a soluble form of LFA3.

Elizabeth Collins

\section{British space}

\section{Waiting for an increased budget}

THE British National Space Centre (BNSC) this week celebrates its first anniversary still awaiting the government's response to its 15-year plan for Britain's presence in space. The blueprint, if accepted, will mean a substantial increase in the $£ 108$ million a year that Britain now

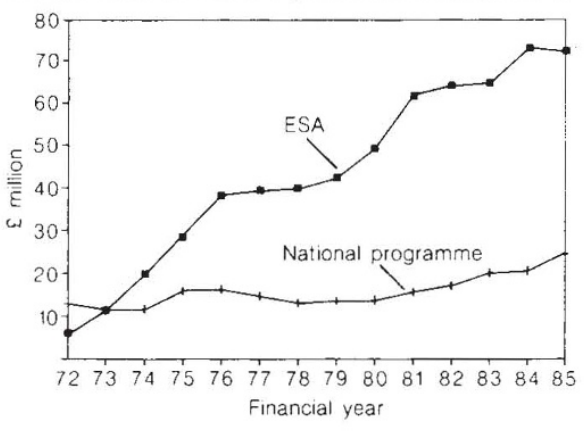

BNSC seeks more funds for space research and a narrowing of the gap between international and domestic projects.

spends on international and domestic space projects.

Britain is under pressure from the United States and Europe to invest heavily. It was the need to respond sensibly to an invitation to participate in the US Space Platform that inspired the creation of BNSC (see Nature 318, 305; 1986).

A ministerial council meeting of the European Space Agency (ESA) in Rome in 1985 generated pressure from Europe. The meeting approved in principle a number of new programmes that would require members' contributions to be increased by 70 per cent in the next three years. France, for example, which already spends five times as much as Britain, has decided to increase its budget by 40 per cent, bringing the total annual expenditure on space to $£ 700$ million.

Roy Gibson, director general of BNSC, says "the European scene is going on, whether we are ready or not", and that BNSC must have a positive response from government within the next few weeks if proper preparations are to be made for the
ESA ministerial council meeting next June at which the final touches to the ESA programme, some lasting more than a decade, will be made.

"Last year we weren't too worried about this deadline in June 1987. . . now we're getting a big edgy because we need these decisions in order to give us the best bargaining position inside ESA."

The British space plan, he says, will require substantial international investment and the domestic budget must be increased to ensure industrial back-up to exploit the new technologies. Much of the money for Britain's contribution to the space platform project, Gibson believes, must come from the government. Although the private sector may eventually benefit, it would find it hard to justify a commercial investment at this stage. "I think it would be very wrong to tell government that it's going to make a lot of money straight away."

BNSC wants the government to commit itself to plans that will span more than a decade and to allocate money at least three years ahead to allow industry to respond and plan accordingly.

To that end, the BNSC plan details the principal areas in which the United Kingdom must develop. These are space science, remote sensing, microgravity, telecommunications (with particular emphasis on mobile communications on land, air and sea), space station, ground/ test/reception facilities, data processing and enabling technologies.

The present budget is culled from the space funds of the Department of Trade and Industry, the Ministry of Defence, the Natural Environment Research Council and the Science and Engineering Research Council. The 280 members of staff are spread between London, the Rutherford Appleton Laboratory in Oxfordshire and Farnborough in Hampshire. The next stage would be to create a permanent role for BNSC and perhaps a permanent home. 